This is the peer reviewed version of the following article: Influence of the type of calcium salt on the cation absorption and firmness of black ripe olives. Pedro García-Serrano, Concepción Romero, Pedro García-García, Manuel Brenes. International Journal of Food Science and Technology (2020), which has been published in final form at https://doi.org/10.1111/ijfs.14739. This article may be used for noncommercial purposes in accordance with Wiley Terms and Conditions for Self-Archiving

\title{
Influence of the type of calcium salt on the cation absorption and firmness of black ripe olives
}

Pedro García-Serrano, Concepción Romero*, Pedro García-García and Manuel Brenes Instituto de la Grasa (IG-CSIC), Building 46, Ctra. Utrera km 1, 41013-Seville, Spain

Correspondence to: Concepción Romero. E-mail: $\underline{\text { c.romero@ @ csic.es }}$ 


\section{Summary}

The preservation of olives intended for processing as black ripe olives must be done in a salt-free environment although it involves the use of calcium addition to retard olive softening. Calcium chloride and calcium lactate were added by up to $1600 \mathrm{mg} \mathrm{Ca} \mathrm{L}^{-1}$ (i) in the preservation liquid of olives before darkening, and (ii) in the cover packing brine. The highest texture and calcium absorption were found in the latter case. In addition, the sensory characteristics of the final product were not affected by the use of any of the

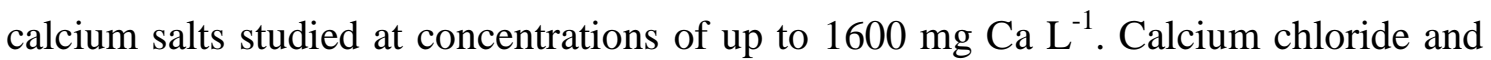
calcium lactate can be employed to obtain higher texture and calcium content in black ripe olives, although it is advisable to add the cation to the cover packing brine of pitted olives rather than to the preservation liquid.

Keywords: ripe olive, texture, calcium, absorption, lactate, chloride 


\section{Introduction}

As calcium is linked to the structural preservation of vegetable tissues, several calcium salts are widely employed to retard softening of fruits and vegetables during their processing and shelf life, in particular calcium chloride, and to a lesser extent, calcium lactate (Manganaris et al. 2005; Silveira et al., 2011). It is well-known that calcium chloride enhances the firmness of naturally black olives (Tassou et al., 2007) and Spanish-style green olives (Jiménez et al., 1997), and we recently detected no differences in the texture of black ripe olives due to the type of calcium salt employed during the preservation of the fruit under acidic conditions (García-Serrano et al., 2020).

It is assumed that calcium inhibits the softening rate of fruits and vegetables because of its interaction with cell wall polysaccharides, particularly pectin substances, according to the egg-box model. However, there is contradictory data regarding this hypothesis. At $\mathrm{pH}$ below 3.8 units, degradation of pure pectins occurred via acid hydrolysis without any effect from calcium on the rate of this reaction, whereas the softening rate of cucumbers was retarded by calcium ions (McFeeters et al., 1995; Krall \& McFeeters 1998). Likewise, the degradation of this cell wall component at $\mathrm{pH}$ above 3.8 occurred through the B-elimination reaction (McFeeters et al., 1991), which was enhanced by divalent cations in pectin solutions and cell wall suspension (Keijbets \& Pilnik 1974; Keijbets et al., 1976). Contradictorily, the softening rate of cucumber mesocarp tissue at $\mathrm{pH}$ above 5 was not affected by calcium ions (McFeeters et al., 1991). In the case of black ripe olives, the lye treatment gave rise to degradation of cell walls due to the loss of pectic, hemicellulosic, and cellulosic polysaccharides (Mafra et al., 2007), which led to a decrease in texture (Georget et al., 2003). However, the firmness of these olives was better with added calcium in the cover brine within a $\mathrm{pH}$ 
range of 6.6-9.0 units (García et al., 1994). It is noteworthy that black ripe olives are packed at pH around 7-9 units (García et al., 2018), and the final product reached a pH close to 7 units (García et al., 2018b), thereby ß-elimination must be the main reaction involved in the softening of these olives during their packing, sterilization and shelf life stages.

In addition to the firming effect, another benefit derived from calcium treatment is the development of enriched or functional foods as calcium intake has been associated with the prevention of bone fragility, hypertension and colon cancer, among others. With this in mind, there have been some studies on partial $\mathrm{NaCl}$ substitution in Spanishstyle green olives with other salts such as $\mathrm{CaCl}_{2}$ (Rodríguez-Gómez et al., 2012). However, calcium absorption in fruit and vegetables depends on many factors, including the fact that the type of salt is relevant (Silveira et al., 2011; Li et al., 2020). Indeed, a direct relationship between calcium uptake and firmness or uronic acid content has not been observed in many studies, which suggests a cross-link of the cation with cell wall polysaccharides other than pectins (Manganaris et al. 2005).

In the case of black ripe olives, there is only one report dealing with the uptake of calcium during the sterilisation stage and its relationship with the firmness of olives when working on a model system (García et al., 1994). In addition, our recent study on calcium and black ripe olives was aimed at investigating the effect of different calcium salts during the preservation stage of olives before the darkening process (GarcíaSerrano et al., 2020). Thus, the main objective of this work has been to study the influence of the type of calcium salt (chloride or lactate), olive cultivar (Hojiblanca, Manzanilla and Cacereña), stage of addition and olive style (whole or pitted) on the relationship between calcium uptake and firmness of processed black ripe olives.

\section{Materials and methods}




\section{Olives}

The experiments were carried out on olives (Olea europaea L.) of the Hojiblanca, Manzanilla and Cacereña $c v s$. Hojiblanca fruits had been stored for a period of six months in industrial fermenters $(10,000 \mathrm{~kg})$ at Olivarera del Genil SCA (Badolatosa, Spain), and Manzanilla and Cacereña $c v s$. were obtained from polyethylene fermenters of $22 \mathrm{~kg}$ capacity stored at the Instituto de la Grasa pilot plant for six months. All olives had been preserved in salt-free acidified solutions under aerobic conditions (GarcíaSerrano et al., 2020).

\section{Darkening, packing and sterilisation processes}

The olives were oxidised in four horizontal cylindrical containers $(20 \mathrm{~cm} \varnothing, 40 \mathrm{~cm}$ long). Three kilograms of olives were covered with 3.0 L of liquid (lye, washing water or ferrous gluconate solution), thus having the same olive/liquid ratio as in industrial tanks. During the entire process, air was bubbled through along the horizontal bottom of the cylinder (20 diffusers).

Olives were treated with one $\mathrm{NaOH}$ solution but in differing concentrations according to the morphological characteristics (firmness) of the cultivar (García-Serrano et al., 2020): 30, 23 and $20 \mathrm{~g} \mathrm{NaOH} \mathrm{L}{ }^{-1}$ for Hojiblanca, Manzanilla and Cacereña cvs., respectively. Once the alkali reached the pit, the fruits were placed in tap water for 20 hours. Subsequently, the olives were put in a new washing solution (tap water) for another day and the $\mathrm{pH}$ of the liquid was maintained at 8.0 units by adding $\mathrm{CO}_{2}$. Finally,

on the third day, the fruits were covered with a ferrous gluconate solution $\left(1 \mathrm{~g} \mathrm{~L}^{-1}\right)$ and aerated for another five hours to fix the black colour formed.

When desired, a portion of the olives were pitted with an olive pitting machine, model DSN (OFM, Dos Hermanas, Spain). For the packaging, A-314 bottles (JUVASA, 
Dos Hermanas, Spain) were used, into which $145 \mathrm{~g}$ of pitted olives and $175 \mathrm{ml}$ of cover brine or $175 \mathrm{~g}$ of whole olives and $145 \mathrm{~mL}$ of liquid were placed respectively. In addition, pitted and whole ripe olives were packed in the same jars but using the same weight of olive flesh/volume of liquid ratio to study the effect of the olive style on calcium absorption.

The cover brine contained $0.15 \mathrm{~g} \mathrm{~L}^{-1}$ ferrous gluconate, $35 \mathrm{~g} \mathrm{~L}^{-1}$ marine salt and the indicated calcium concentration added as lactate (Puracal PP Food, Purac Biochem BV, Nederlands) or chloride (PanReac AppliChem, Spain). The tap water used (EMASESA, Sevilla, Spain) in the different solutions had a Ca average content of $35 \mathrm{mg} \mathrm{L}^{-1}$.

The jars were closed and sterilised at $121^{\circ} \mathrm{C}$ in a computer-controlled Steriflow retort (Madinox, Barcelona, Spain) to reach a lethality value of $15 \mathrm{~F}_{0}$.

All oxidation and packing experiments were run in duplicate.

\section{Experimental designs}

Influence of the stage of calcium addition during olive processing and the type of calcium salt on the calcium uptake and firmness of olives

In this experiment, calcium was added either before the darkening stage or in the packing solution. Hojiblanca olives that had been previously stored for six months (3 $\mathrm{kg}$ ) were placed into $5 \mathrm{~L}$ containers and covered with $1.75 \mathrm{~L}$ of the same storage liquid which was then spiked with calcium lactate (Purac Bioquímica, Barcelona, Spain) and calcium chloride (PanReac AppliChem, Spain) to reach 400, 800 and $1600 \mathrm{mg} \mathrm{L}^{-1}$ of the cation. As a control, olives in the same storage liquid without $\mathrm{Ca}$ addition were also studied. Subsequently, all containers were preserved under controlled temperatures $\left(22 \pm 3^{\circ} \mathrm{C}\right)$ for three months. 
All olives were darkened and pitted as explained above, and those without calcium added during the preservation stage were also packed with different amounts of calcium chloride and lactate (400, 800 and $\left.1600 \mathrm{mg} \mathrm{L}^{-1}\right)$. All olives were analysed two months after packing.

Influence of the type of calcium salt and olive style on the characteristics of black ripe olives

Olives of the Manzanilla and Cacereña cultivars without calcium added during the preservation stage were darkened as explained above. Whole and pitted fruits were packed with $0,400,800$ and $1600 \mathrm{mg} \mathrm{L}^{-1}$ calcium added in the cover brine. After sterilisation, the jars were maintained at ambient temperature for two months before analysis.

A new experiment was carried out to know more about the influence of the olive style on calcium uptake and its relationship with the firmness of the product. Olives of the Hojiblanca cultivar without calcium added during the preservation stage were darkened as explained above and packed in the aforementioned A-314 bottles. However, in this case, the olive flesh/cover brine ratio was similar for both whole and pitted fruit, so that $120 \mathrm{~g}$ of pitted fruit or $140 \mathrm{~g}$ of whole fruit were packed with 120 $\mathrm{mL}$ of brine which was spiked with 400 and $1600 \mathrm{mg} \mathrm{L}^{-1}$ of calcium. Two months after packing, firmness and Ca content in both olives and cover brine were determined.

\section{Study of Ca fixation and its distribution in the olive phases}

Hojiblanca olives were darkened, pitted and packed in brine without calcium added (tap water) or spiked with $1600 \mathrm{mg} \mathrm{L}^{-1}$ of the cation. Calcium was analysed in the solid and liquid (juice) phases of the olives before darkening, after darkening and two months after packing. To obtain the juice, fruits were crushed and the paste was centrifuged at 
$3500 \mathrm{~g}$ for five minutes. Calcium was analysed in the supernatant (juice) and the solid paste. The calcium content in each phase $\left(\mathrm{mg} \mathrm{kg}^{-1}\right.$ olive pulp) was calculated, taking into account the moisture of the fruits at the end of each stage.

In another experiment, $100 \mathrm{~g}$ of Hojiblanca olives taken before and after darkening were crushed and the paste was centrifuged at $3500 \mathrm{~g}$ for five minutes. The liquid was removed and the solid was mixed with $25 \mathrm{~mL}$ of distilled water and the mixture was stirred for 15 minutes. Subsequently, the mixture was centrifuged at $3500 \mathrm{~g}$ for five minutes and the liquid was removed. This operation was repeated five times. Then, the washed pulp was put into contact with $15 \mathrm{~mL}$ of solutions containing 50, 100, 200 and $400 \mathrm{mg} \mathrm{L}^{-1}$ of calcium and the mixture was stirred for one hour at room temperature. Finally, the calcium content was analysed in the liquid and the washed pulp.

\section{Analyses}

Firmness and superficial colour of olives

The firmness of olives was measured with a Texture Analyzer TA.TX plus (Stable Microsystems, Godalming, UK) using a Kramer shear-compression cell. Firmness was the average of 10 replicated measurements and it was expressed as Newton $100 \mathrm{~g}^{-1}$ pitted olives (García-Serrano et al., 2020). The crosshead speed was $200 \mathrm{~mm} \mathrm{~min}^{-1}$.

The superficial colour of olives was measured using a BYK-Gardner model 9000 Color-view spectrophotometer (Silver Spring, MD, USA). The colour was expressed as reflectance at $700 \mathrm{~nm}\left(R_{700}\right)$. Lower reflectance values indicate darker fruit. Results were the average of 10 determinations (García et al., 2014).

\section{Calcium and Iron}


For the determination of metals in liquids and olives, $1 \mathrm{~mL}$ or $1 \mathrm{~g}$, weighed exactly, was digested with $\mathrm{HNO}_{3}$ at $120^{\circ} \mathrm{C}$ over eight hours in a DigiPREP (Canada) (García et al., 2018).

Calcium and iron were analysed with a GBC model 932 AA (Victoria, Australia) atomic absorption spectrometer equipped with two multi-element hollow cathode lamps, (Ca, Mg, $\mathrm{Cu}, \mathrm{Zn})$ (Photrompty, Victoria, Australia) and (Cu, Cr, $\mathrm{Co}, \mathrm{Fe}, \mathrm{Mn}$, and Ni) (GBC, Victoria, Australia). An air-acetylene flame was used.

Moisture The water content of pulp was determined by weighing $10 \mathrm{~g}$ of the sample and then oven drying at $105^{\circ} \mathrm{C}$ to constant weight.

\section{Sensory analysis of ripe olives}

The black ripe olives were tested according to the "Method for sensory analysis of table olives" in the normalised testing room of the Instituto de la Grasa (IOC, International Olive Council, 2011). This method classifies olives commercially through the use of descriptors related to the perception of negative sensations ("abnormal flavour"). Gustatory attributes (salty, bitter and acidic) and kinaesthetic sensations (hardness, fibrousness and crunchiness) were also assessed.

Three or four olives were presented to each taster in a normalised glass according to the standard COI/ T.20/Doc. No 5 (Glass for oil tasting). Panellists (nine trained testers among the staff of Instituto de la Grasa) were required to indicate the intensity they perceived for each attribute on the scales of the profile sheet provided. The left-hand extreme indicated absence of the attribute, while the right-hand extreme was maximum perception. The scale measured $10 \mathrm{~cm}$ long and the intensity ranged from 1 to 11 .

The values of the attributes were expressed as the median of the individual data and the variability by robust standard deviation. 
Statistical analyses

An ANOVA analysis was applied to know the significance effects $(p<0.05)$, followed by the Duncan's multiple range test to compare the mean values for each experience using Statistica software version 7.0 (Statistica for Windows, Tulsa, Okla., U.S.A.). In the sensory analysis, differences were considered significant when confidence intervals of the medians $(p<0.05)$ did not overlap.

\section{Results and discussion}

\section{Influence of the stage of calcium addition in Hojiblanca $c v$.}

The evolution of the calcium content in the preservation liquid of Hojiblanca olives spiked with calcium chloride and calcium lactate is illustrated in Fig. 1. The decline of calcium in these liquids indicated that at least 30 days was needed to absorb most of the cation in the olive pulp, regardless of the type of calcium salt employed. In fact, the calcium concentration in the unprocessed olives was $752 \mathrm{mg} \mathrm{kg}^{-1}$ and, after 68 days of preservation, this value reached 844,902 and $1070 \mathrm{mg} \mathrm{kg}^{-1}$ respectively when the preservation liquid was spiked with calcium from lactate salt up to 400, 800 and 1600 $\mathrm{mg} \mathrm{L}^{-1}$ respectively of the ion. Similar results were found when using chloride salt 836,922 and $1078 \mathrm{mg} \mathrm{kg}^{-1}$ respectively when the preservation liquid was spiked with the ion up to 400,800 and $1600 \mathrm{mg} \mathrm{L}^{-1}$ respectively. This phenomenon occurred at the acidic $\mathrm{pH}$ of the liquids ( $<4$ units) and the anion of the calcium salt did not influence the diffusion rate of the cation.

Subsequently, olives were elaborated following the black ripe olive processing method, and the concentration of calcium and the firmness of the final product can be seen in Fig. 2. When the higher concentration of calcium was added to the preservation 
liquid, the higher content of the cation remained in the pulp of the final product. This data revealed that the type of calcium salt tested at the same calcium concentration did not have any influence on the uptake of the cation during the preservation stage and leaching during the elaboration process (darkening, packing and shelf life). Previous works found similar results (Manganaris et al. 2005; Silveira et al., 2011).

Surprisingly, olives were enriched in a higher amount of calcium when the cation was added in the cover brine of packing rather than in the preservation liquid (Fig. 2). It seems that the absorption of this cation in the pulp was stronger in processed olives than in preserved fruit, and this phenomenon occurred for both calcium salts tested. We think that it could be related to the level of pectin esterification being lower in alkali processed olives than preserved olives.

As expected, higher firmness of olives was achieved with increased concentrations of calcium without any influence from the type of calcium salt employed (Fig. 2). In addition, olives with calcium added in the packing stage had significantly higher texture than those with the calcium added in the preservation liquid, irrespective of the type of calcium salt used. It is noteworthy that the firming effect of calcium occurred at $\mathrm{pH}$ close to neutrality which confirmed previous works (Keijbets \& Pilnik 1974). From a practical point of view, olives preserved in a salt-free solution need the addition of calcium to maintain fruit texture (García-Serrano et al., 2020). The cation can be added at the beginning of the preservation stage or prior to the darkening process.

Effect of olive style on calcium absorption and firmness in Manzanilla and Cacereña cvs.

Texture is a crucial quality parameter that must be maintained to a large extent throughout the estimated three years of shelf life (García et al., 2014). Among Spanish 
black ripe olives, the Manzanilla and Cacereña cultivars currently show a less firm texture than the Hojiblanca cultivar, therefore these assays were conducted with the former cultivars. Black ripe olives of the Manzanilla cultivar showed higher texture when packed without the stone (pitted) than whole, if calcium was added in the cover brine (Fig. 3A), this effect being significant for the whole range of calcium tested. This behaviour was only a trend for Cacereña olives, probably due to their initial texture being less firm than the Manzanilla (Fig. 3B). It must also be noted that the data displayed in Fig. 3 corresponds to the mean values obtained with both calcium salts.

The higher texture obtained in pitted rather than whole olives was linked to the former fruit having a higher uptake of calcium than the latter (Table 1), regardless of the type of calcium salt and olive cultivar.

Another important quality parameter of black ripe olives is their black colour, which could be influenced by the addition of the cation in the cover brine, either favouring the formation of the colour or inhibiting the diffusion of fixing iron into the olive flesh. However, from the data reported in Table 1, it can be deduced that calcium did not affect this parameter nor the absorption of iron in the final product since, for example, in Manzanilla, all packages of the same style statistically had the same final iron concentration, $53.2 \pm 1.5 \mathrm{mg} \mathrm{kg}{ }^{-1}$ for pitted and $41.1 \pm 1.3 \mathrm{mg} \mathrm{kg}^{-1}$ for whole, respectively. The greater absorption of iron in the pitted olives than in the whole olives was responsible for the darker colour in the former (lower $\mathrm{R}_{700}$ ). (Table 1$)$.

\section{Influence of olive style on firmness and calcium absorption in Hojiblanca cv.}

A question arose from the results presented in Fig. 3 and Table 1, as to why pitted olives had a higher content of calcium than whole olives and, consequently, better firmness. In order to answer this question, a new packing experiment was carried out with whole and 
pitted Hojiblanca olives with the same olive flesh/cover brine ratio. Again, pitted olives were significantly firmer than whole olives with calcium added from 400 to $1600 \mathrm{mg} \mathrm{L}^{-}$ ${ }^{1}$ (Fig. 4), and this behaviour correlated with a higher uptake of the cation in the pitted than in the whole olives. Likewise, the concentration of Ca was lower in the cover brine of pitted than whole olives, which confirmed the higher absorption of the cation in the former olives, probably due to the higher area of diffusion presented by this type of olives than those with the stone.

Absorption of calcium in the olive phases of Hojiblanca $\mathrm{cv}$. during ripe olive processing

Fig. 5 shows the calcium content in the solid phase and the liquid phase (juice) of Hojiblanca olives during their processing as black ripe olives. First, the calcium content in the solid phase of the olives before the darkening stage was higher than in the liquid phase, and this ratio of calcium in solid/calcium in liquid phases slightly increased after the darkening stage, as a slight loss of calcium content in the juice was produced due to its diffusion into the different solutions in which the fruits were placed. Also, losses of cation were not observed in the solid phase.

In contrast, this ratio significantly increased without calcium added in the cover brine or even with calcium addition (1600 $\mathrm{mg} \mathrm{L}^{-1}$ ) after packing, sterilisation and preservation of the product at room temperature for two months. It seemed that the heating treatment increased the absorption of the cation to a large extent in the solid phase of olives, which was already proven (García et al., 2018).

To understand this phenomenon better, the olive paste was thoroughly washed and put into contact with calcium solutions of increasing concentration. The results depicted in Fig. 6 disclosed that most of the calcium was absorbed in the solid phase of olives not submitted to darkening, but this uptake was almost complete with darkened olives 
within the range of calcium tested. All this data confirmed that olive paste is a good absorbent material for calcium and other metals, as has been proposed for the bioremediation of contaminated solutions (Llay R et al., 2019).

Influence of calcium on sensory characteristics of Manzanilla and Cacereña cvs. black ripe olives

The sensory analysis carried out on black olives packed with calcium addition in the cover brine revealed that none of the calcium salts tested (chloride and lactate) gave rise to an abnormal flavour in the final product, neither in Manzanilla nor Cacereña olives (Table 2). In addition, olives did not increase in bitterness due to the addition of calcium up to $1600 \mathrm{mg} \mathrm{L}^{-1}$ in the cover brine, regardless of the type of calcium salt employed. This data is in agreement with that recently found in olives enriched in a lower concentration of calcium at the beginning of the preservation stage (García-Serrano et al., 2020). It must be noted that higher concentrations of calcium gave rise to bitterness in natural black olives (Panagou et al., 2011). Moreover, a concentration of calcium higher than $1600 \mathrm{mg} \mathrm{L}^{-1}$ may not be needed to inhibit the softening rate of olives due to the reported saturation effect of the cation (García et al., 1994). Finally, tasters detected greater hardness in olives spiked with calcium, regardless of the type of calcium salt and olive cultivar, which is in accordance with objective measurements obtained by shearcompression.

\section{Conclusion}

This study found that the type of calcium salt (chloride and lactate) did not influence the calcium uptake or texture of black ripe olives. By contrast, the stage of calcium addition and the olive style influenced the calcium uptake to a large extent, and consequently the 
firmness of the olives, the highest firmness and $\mathrm{Ca}$ uptake being achieved in pitted olives with calcium added in the cover packing brine. The high absorption of this cation in the solid phase of the olives instead of the liquid phase (juice) was also discovered. Hence, the addition of any of the calcium salts tested up to $1600 \mathrm{mg} \mathrm{L}^{-1}$ exerted a positive effect on olive texture and enrichment in this mineral without any sensory defect being observed, including bitterness.

\section{Acknowledgements}

This work was supported by the Spanish Government (Project AGL2016-76820-R, AEI/FEDER, UE).

\section{Conflicts of interest}

The authors declare no conflicts of interest.

\section{Data Availability Statement}

Research data are not shared.

\section{Ethical Guidelines}

Ethics approval was not required for this research.

\section{References}

García, P., Brenes, M. \& Garrido, A. (1994). Effects of pH and salts on the firmness of canned ripe olives. Sciences des Aliments, 14, 159-172.

García, P., Romero, C. \& Brenes, M. (2018). Influence of iron redox state on black ripe olive processing. Journal of the Science of Food and Agricultural, 98, 4653-4658. 
García, P., Romero, C. \& Brenes, M. (2018b). Bioactive substances in black ripe olives produced in the USA and Spain. Journal of Food Composition and Analysis, 66, 193-198.

García, P., Sánchez, A.H. \& Garrido, A. (2014). Changes of physicochemical and sensory characteristics of packed ripe olives from Spanish cultivars during shelflife. International Journal of Food Science and Technology, 49, 895-903.

García-Serrano, P., Romero, C., Medina, E., García-García, P., de Castro, A. \& Brenes, M. (2020). Effect of calcium on the preservation of green olives intended for black ripe olive processing under free-sodium chloride conditions. LWT-Food Science and Technology, 118, 108870.

Georget, D., Andrew, C., Smith, A.C., Keith, W., Waldron, K.W. \& Rejano, L. (2003). Effect of 'Californian' process on the texture of Hojiblanca olive (Olea europaea L) harvested at different ripening stages. Journal of the Science of Food and Agricultural, 83, 574-579.

International Olive Council (IOC), Method for the sensory analysis of table olives. COI/OT/MO 1/Rev.2 No 1. (2011).

Jiménez, A., Heredia, A.M., Guillén, R. \& Fernández-Bolaños, J. (1997). Correlation between soaking conditions, cation content of cell wall and olive firmness during 'Spanish green olive' processing. Journal of Agricultural and Food Chemistry, 45, $1653-1658$.

Keijbets, M.J.H. \& Pilnik, W. (1974). ß-Elimination of pectin in the presence of anions and cations. Carbohydrate Research, 33, 359-362.

Keijbets, M.J.H., Pilnik, W. \& Vaal, J.F.A. (1976). Model studies on behavior of pectic substances in the potato cell wall during boiling. Potato Research, 19, 289-303. 
Krall, S.M. \& McFeeters, R.F. (1998). Pectin hydrolysis: effect of temperature, degree of methylation, $\mathrm{pH}$, and calcium on hydrolysis rates. Journal of Agricultural and Food Chemistry, 46, 1311-1315.

Li, X., Zhi, H., Li, M., Liu, Q., Xu, J. \& Dong, Y. (2020). Cooperative effects of slight acidic electrolyzed water combined with calcium sources on tissue calcium content, quality attributes, and bioactive compounds of "Jiancui" jujube. Journal of the Science and Food Chemistry, 100, 184-192.

Llay, R., Baba, A. \& Kavdir, Y. (2019). Removal of metals and metalloids from acidic mining lake (AML) using olive oil solid waste (OSW). International Journal of Environmental Science and Technology, 16, 4047-4058.

Mafra, I., Barros, A. \& Coimbra, M.A. (2007). The combined effects of black oxidising table olive process and ripening on the cell wall polysaccharides of olive pulp. Carbohydrate Polymers, 68, 647-657.

Manganaris, G.A., Vasilakakis, M., Diamantidis, G. \& Mignani, I. (2005). Effect of calcium additives on physicochemical aspects of cell wall pectin and sensory attributes of canned peach (Prunus persica (L) Batsch cv Andross). Journal of the Science of Food and Agricultural, 85, 1773-1778.

McFeeters, R.F., Brenes, M. \& Fleming, H.P. (1995). Softening rates of fermented cucumber tissue: effects of $\mathrm{pH}$, calcium, and temperature. Journal of Food Science, 6, 786-788.

McFeeters, R.F. \& Fleming, H.P. (1991). PH effect on calcium inhibition of softening of cucumber mesocarp tissue. Journal of Food Science, 56, 730-733.

Panagou, E.Z., Hondrodimou, O., Mallouchos, A. \& Nychas, G.J.E. (2011). A study of the implications of $\mathrm{NaCl}$ reduction in the fermentation profile of Conservolea natural black olives. Food Microbiology, 28, 1301-1307. 
Rodríguez-Gómez, F., Bautista-Gallego, J., Romero-Gil, V., Arroyo-López, F.N., Garrido-Fernández, A. \& García-García, P. (2012). Effects of salt mixtures on Spanish green table olive fermentation performance. Food Science and Technology, 46, 56-63.

Silveira, A.C., Aguayo, E., Chisari, M. \& Artes, F. (2011). Calcium salts and heat treatment for quality retention of fresh-cut "Galia" melon. Postharvest Biology and Technology, 62, 67-84.

Tassou, C.C., Katsaboxakis, C.Z., Georget, D., Parker, M.L., Waldron, K.W., Smith, A.C. \& Panagou, E.Z. (2007). Effect of calcium chloride on mechanical properties and microbiological characteristics of cv. Conservolea naturally black olives fermented at different sodium chloride levels. Journal of the Science of Food and Agricultural, 87, 1123-1131. 
Table 1 Influence of the type of calcium salt added to the packing brine on the colour and cation absorption of black ripe olives of the Manzanilla and Cacereña cultivars.

\begin{tabular}{|c|c|c|c|c|c|c|c|c|c|}
\hline \multirow[b]{3}{*}{$\begin{array}{c}\text { Type of } \\
\text { salt } \\
\end{array}$} & \multirow[b]{3}{*}{$\begin{array}{c}\text { Ca added } \\
\left(\mathrm{mg} \mathrm{L}^{-1}\right)\end{array}$} & \multicolumn{4}{|c|}{ Calcium in olive flesh $\left(\mathrm{mg} \mathrm{kg}^{-1}\right)$} & \multicolumn{4}{|c|}{ Superficial colour $\left(\mathbf{R}_{700}\right)$} \\
\hline & & \multicolumn{2}{|c|}{ Manzanilla cultivar } & \multicolumn{2}{|c|}{ Cacereña cultivar } & \multicolumn{2}{|c|}{ Manzanilla cultivar } & \multicolumn{2}{|c|}{ Cacereña cultivar } \\
\hline & & Pitted & Whole & Pitted & Whole & Pitted & Whole & Pitted & Whole \\
\hline Control & 0 & $591 \pm 56 f^{\mathrm{x}, \mathrm{y}}$ & $550 \pm 16 f$ & $302 \pm 16 f$ & $317 \pm 11 f$ & $3.5 \pm 0.2 b$ & $4.3 \pm 0.1 \mathrm{a}$ & $3.0 \pm 0.1 \mathrm{~b}$ & $3.9 \pm 0.3 \mathrm{a}$ \\
\hline \multicolumn{10}{|l|}{ Chloride } \\
\hline & 400 & $814 \pm 92 \mathrm{~cd}$ & $681 \pm 9 \mathrm{e}$ & $573 \pm 39 d$ & $453 \pm 30 \mathrm{e}$ & $3.5 \pm 0.2 b$ & $4.0 \pm 0.1 \mathrm{a}$ & $3.0 \pm 0.4 \mathrm{~b}$ & $3.7 \pm 0.2 \mathrm{a}$ \\
\hline & 800 & $983 \pm 59 b$ & $884 \pm 2 d$ & $726 \pm 7 c$ & $550 \pm 35 d$ & $3.5 \pm 0.2 b$ & $4.1 \pm 0.2 \mathrm{a}$ & $3.0 \pm 0.3 b$ & $4.0 \pm 0.2 \mathrm{a}$ \\
\hline & 1600 & $1404 \pm 3 a$ & $1231 \pm 53 b$ & $1020 \pm 21 \mathrm{a}$ & $850 \pm 28 b$ & $3.4 \pm 0.2 b$ & $4.3 \pm 0.1 \mathrm{a}$ & $3.1 \pm 0.3 b$ & $3.8 \pm 0.5 \mathrm{a}$ \\
\hline \multicolumn{10}{|l|}{ Lactate } \\
\hline & 400 & $807 \pm 92 \mathrm{~cd}$ & $731 \pm 53 \mathrm{~cd}$ & $582 \pm 22 d$ & $493 \pm 9 \mathrm{e}$ & $3.5 \pm 0.1 \mathrm{~b}$ & $4.1 \pm 0.1 \mathrm{a}$ & $2.9 \pm 0.2 b$ & $3.9 \pm 0.5 \mathrm{a}$ \\
\hline & 800 & $995 \pm 58 b$ & $865 \pm 64 d$ & $694 \pm 33 c$ & $555 \pm 21 d$ & $3.3 \pm 0.2 b$ & $4.3 \pm 0.2 \mathrm{a}$ & $3.0 \pm 0.2 b$ & $4.0 \pm 0.1 \mathrm{a}$ \\
\hline & 1600 & $1395 \pm 3 a$ & $1178 \pm 9 b$ & $1025 \pm 24 \mathrm{a}$ & $890 \pm 21 b$ & $3.5 \pm 0.2 b$ & $4.1 \pm 0.1 \mathrm{a}$ & $3.1 \pm 0.1 \mathrm{~b}$ & $3.9 \pm 0.1 \mathrm{a}$ \\
\hline
\end{tabular}

${ }^{\mathrm{x}}$ Mean values of duplicates \pm standard deviation. ${ }^{\mathrm{y}}$ For each cultivar values of pitted or whole fruits followed by the same letter do not differ $(\mathrm{p}<0.05)$ in significance according to Duncan's multiple-range test. 
Table 2 Influence of the type of calcium salt on the sensory characteristics of the pitted black ripe olives six months after packing.

\begin{tabular}{|c|c|c|c|c|c|c|c|c|c|}
\hline \multirow[b]{2}{*}{ Type of salt } & \multirow[b]{2}{*}{$\begin{array}{c}\text { Ca added } \\
\left(\mathrm{mg} \mathrm{L}^{-1}\right)\end{array}$} & \multicolumn{4}{|c|}{ Manzanilla cultivar } & \multicolumn{4}{|c|}{ Cacereña cultivar } \\
\hline & & $\begin{array}{l}\text { Abnormal } \\
\text { flavour }\end{array}$ & Salty & Bitter & Hardness & $\begin{array}{l}\text { Abnormal } \\
\text { flavour }\end{array}$ & Salty & Bitter & Hardness \\
\hline Control & 0 & $1.0 \pm 0.1 \mathrm{a}^{\mathrm{x}, \mathrm{y}}$ & $5.8 \pm 0.1 b$ & $5.5 \pm 0.2 \mathrm{a}$ & $4.5 \pm 0.2 b$ & $1.0 \pm 0.1 \mathrm{a}$ & $5.6 \pm 0.2 \mathrm{a}$ & $5.5 \pm 0.2 \mathrm{a}$ & $4.2 \pm 0.2 b$ \\
\hline \multicolumn{10}{|l|}{ Chloride } \\
\hline & 400 & $1.2 \pm 0.1 \mathrm{a}$ & $5.8 \pm 0.1 b$ & $5.8 \pm 0.2 \mathrm{a}$ & $5.8 \pm 0.4 \mathrm{a}$ & $1.0 \pm 0.1 \mathrm{a}$ & $5.8 \pm 0.5 \mathrm{a}$ & $5.5 \pm 0.2 \mathrm{a}$ & $4.5 \pm 0.5 b$ \\
\hline & 800 & $1.3 \pm 0.2 \mathrm{a}$ & $5.7 \pm 0.3 b$ & $5.7 \pm 0.2 \mathrm{a}$ & $5.8 \pm 0.2 \mathrm{a}$ & $1.0 \pm 0.1 \mathrm{a}$ & $6.0 \pm 0.1 \mathrm{a}$ & $5.6 \pm 0.2 \mathrm{a}$ & $5.3 \pm 0.3 \mathrm{ab}$ \\
\hline & 1600 & $1.4 \pm 0.2 \mathrm{a}$ & $6.0 \pm 0.5 \mathrm{a}$ & $6.0 \pm 0.2 \mathrm{a}$ & $6.3 \pm 0.2 \mathrm{a}$ & $1.3 \pm 0.2 \mathrm{a}$ & $5.8 \pm 0.4 \mathrm{a}$ & $6.0 \pm 0.2 \mathrm{a}$ & $5.8 \pm 0.2 \mathrm{a}$ \\
\hline \multicolumn{10}{|l|}{ Lactate } \\
\hline & 400 & $1.0 \pm 0.0 \mathrm{a}$ & $5.8 \pm 0.2 b$ & $5.8 \pm 0.2 \mathrm{a}$ & $5.5 \pm 0.3 \mathrm{a}$ & $1.0 \pm 0.1 \mathrm{a}$ & $6.0 \pm 0.1 \mathrm{a}$ & $5.7 \pm 0.1 \mathrm{a}$ & $5.0 \pm 0.2 \mathrm{ab}$ \\
\hline & 800 & $1.0 \pm 0.1 \mathrm{a}$ & $5.5 \pm 0.4 b$ & $5.5 \pm 0.3 \mathrm{a}$ & $5.6 \pm 0.3 \mathrm{a}$ & $1.2 \pm 0.1 \mathrm{a}$ & $5.8 \pm 0.1 \mathrm{a}$ & $5.7 \pm 0.1 \mathrm{a}$ & $5.6 \pm 0.1 \mathrm{a}$ \\
\hline & 1600 & $1.0 \pm 0.1 \mathrm{a}$ & $5.6 \pm 0.2 b$ & $5.6 \pm 0.2 \mathrm{a}$ & $6.0 \pm 0.1 \mathrm{a}$ & $1.3 \pm 0.2 \mathrm{a}$ & $5.7 \pm 0.2 \mathrm{a}$ & $5.7 \pm 0.2 \mathrm{a}$ & $6.0 \pm 0.2 \mathrm{a}$ \\
\hline
\end{tabular}

${ }^{\mathrm{x}}$ Mean values of $\mathrm{n}=9 \pm$ robust standard deviation. ${ }^{\mathrm{y}}$ For each column median values followed by the same letter do not differ $(\mathrm{p}<0.05)$ in significance due to overlapping of their corresponding confidence intervals. 


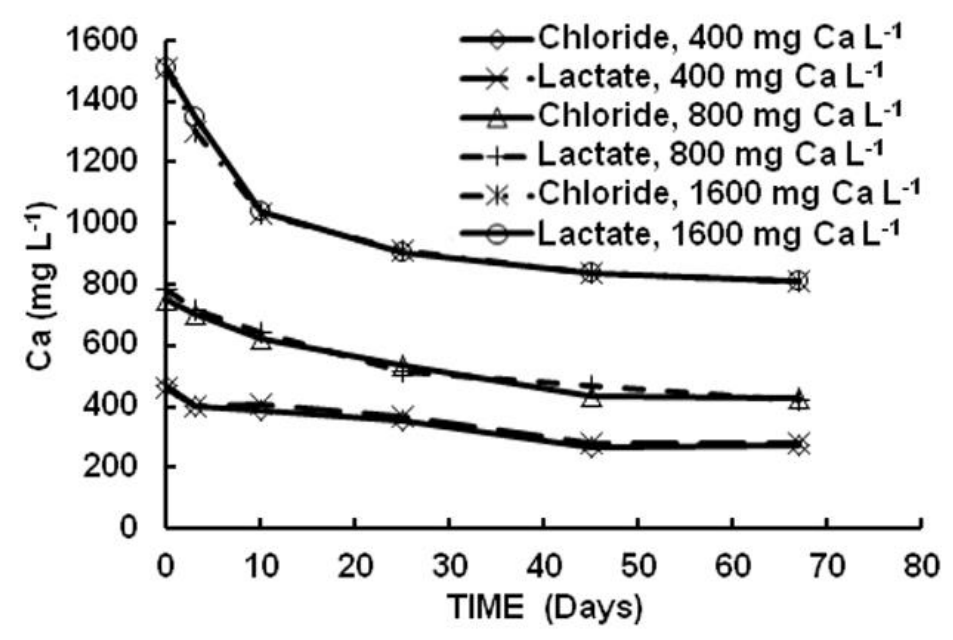

Figure 1. Evolution of calcium in the preservation liquids of Hojiblanca olives spiked with calcium chloride and calcium lactate before the darkening process. Bars of duplicates are depicted for each point. 

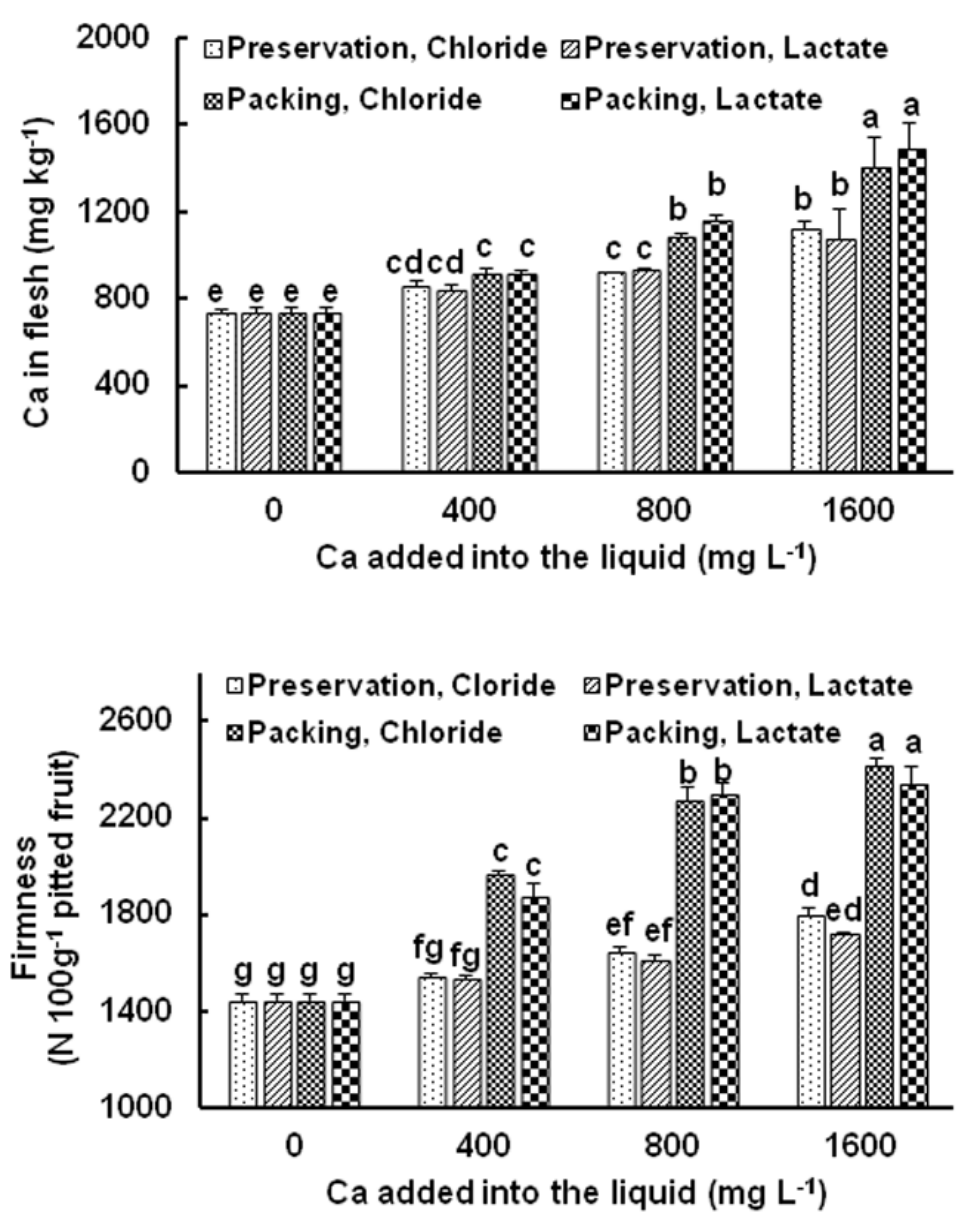

Figure 2. Influence of the type of calcium salt (chloride, lactate) and stage of the cation addition (preservation liquid, packing brine) on the calcium content and firmness in Hojiblanca fruits processed as black ripe olives. The firmness value of the olives before

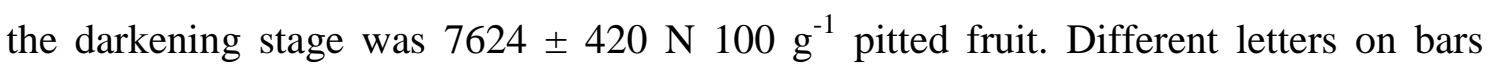
indicate significant differences according to a Duncan's multiple-range test $(P<0.05)$. 

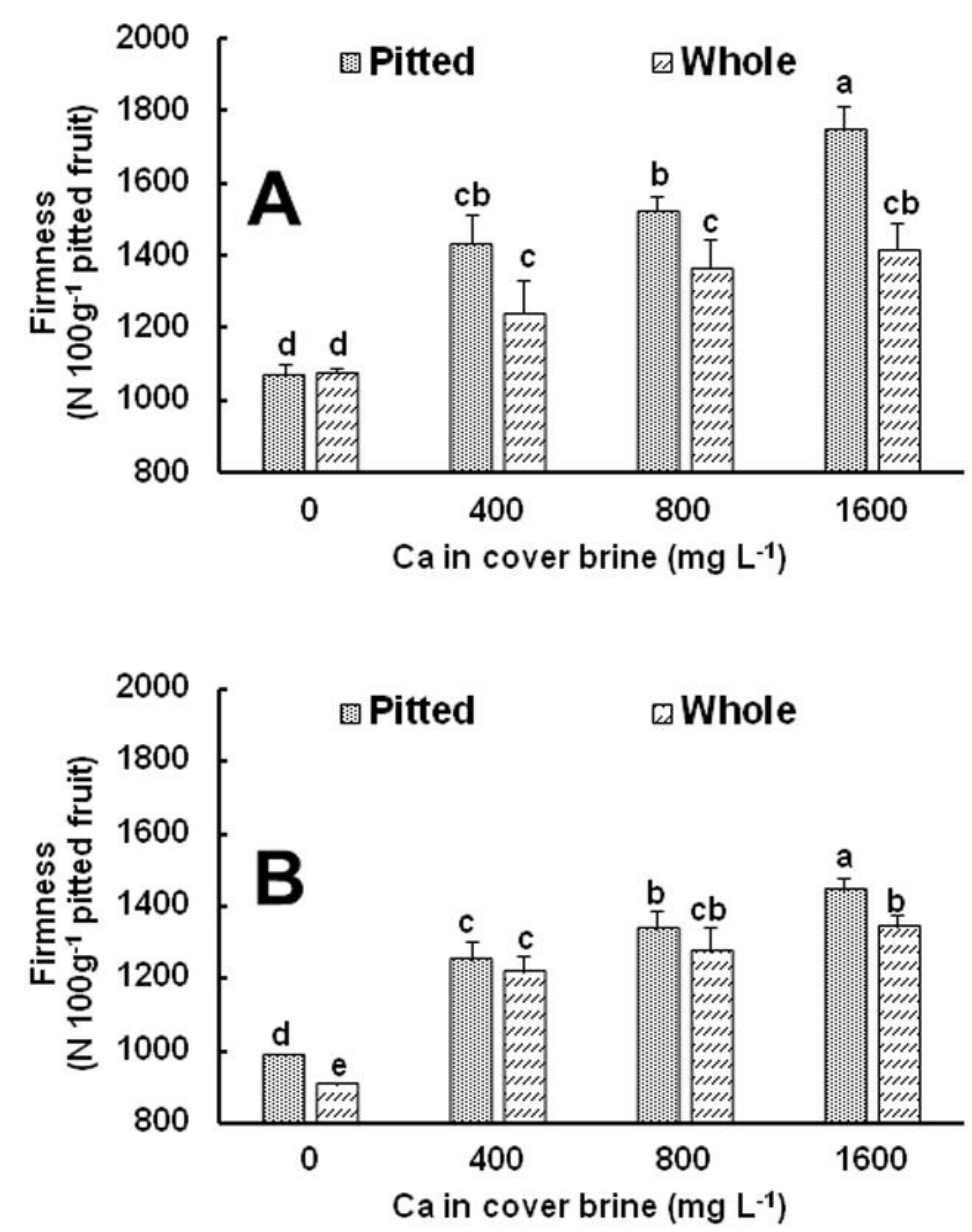

Figure 3. Firmness of pitted and whole olives packed with cover brine that was spiked with different amounts of calcium. Each value is the average of four samples, two spiked with calcium chloride and two with calcium lactate. Different letters on bars indicate significant differences according to a Duncan's multiple-range test $(P<0.05)$. A, Manzanilla cultivar; B, Cacereña cultivar. 

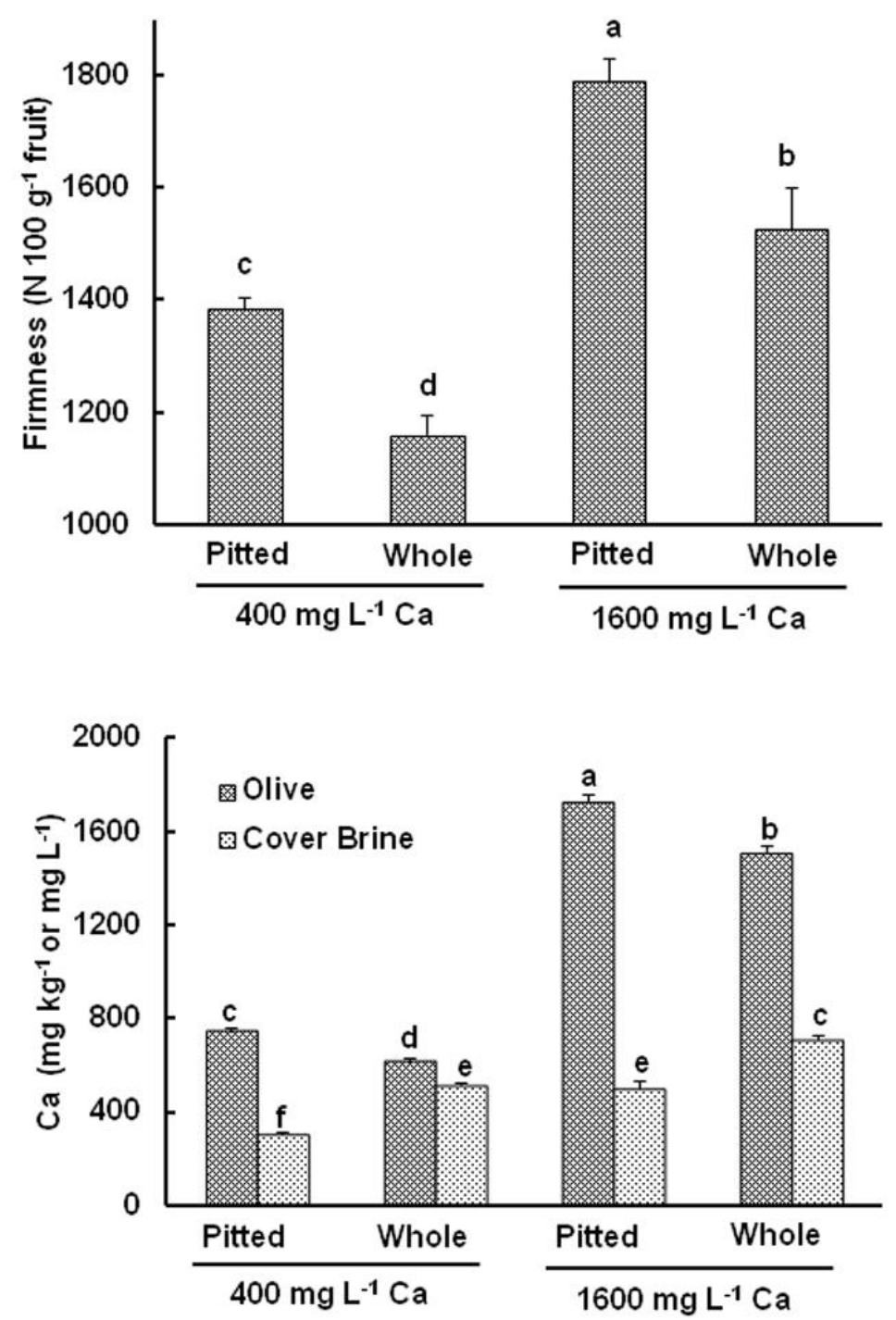

Figure 4. Influence of the black ripe olive style on the firmness and calcium absorption of the Hojiblanca cultivar. Olives were packed with the same fruit/cover brine ratio irrespective of the olive style type. The concentration of calcium in the olive pulp before packing was $610 \pm 25 \mathrm{mg} \mathrm{kg}^{-1}$. Different letters on bars indicate significant differences according to a Duncan's multiple-range test $(P<0.05)$. 


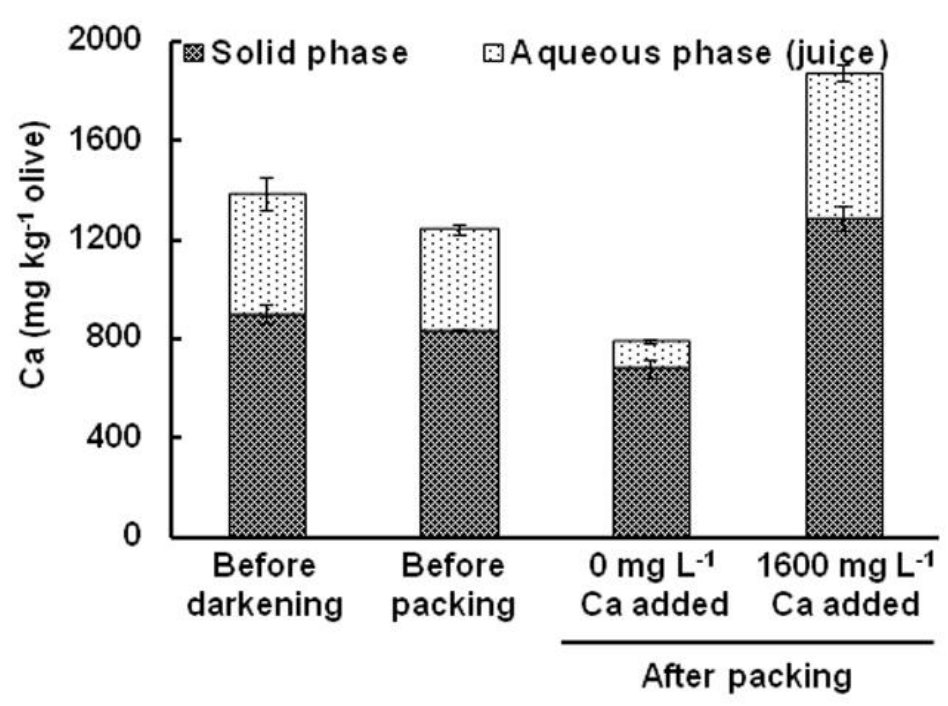

Figure 5. Influence of the stage of olive processing on the distribution of calcium in the two fruit phases: solid and aqueous (juice). Bars mean standard deviation of duplicates. Assays were carried out with the Hojiblanca cultivar. 


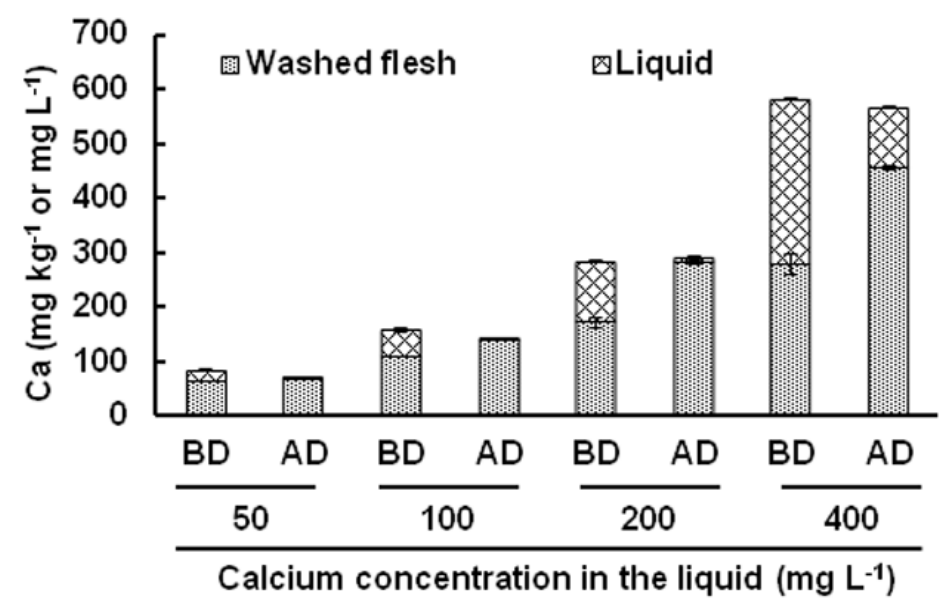

Figure 6. Effect of the darkening stage on the absorption of calcium in the Hojiblanca olive flesh. Washed olive paste before (BD) and after darkening (AD) was put into contact with increasing concentrations of calcium chloride and the distribution of the cation was analysed in the two olive phases (washed flesh and liquid). Bars of duplicates are depicted for each point. 